\title{
The Effect of Self-Efficacy, Caring and Organizational Commitment on Disaster Preparedness of Nurses
}

\section{Waqid Sanjaya}

Study Program of Bachelor Nursing, Sekolah Tinggi Ilmu Kesehatan Sukabumi, Sukabumi, Indonesia

\section{ORCID}

Waqid Sanjaya: https://orcid.org/0000-0001-5198-5346

Corresponding Author: Waqid

Sanjaya; email:

waqids01@gmail.com

Published: 7 February 2022

Publishing services provided by

Knowledge E

(c) Waqid Sanjaya. This article is distributed under the terms of the Creative Commons

Attribution License, which

permits unrestricted use and

redistribution provided that the

original author and source are

credited.

Selection and Peer-review under the responsibility of the IVCN Conference Committee.

\section{G OPEN ACCESS}

\begin{abstract}
Preparedness is a series of activities carried out to anticipate disasters through appropriate and efficient organizational steps. Nurses are one of the main actors in disaster mitigation in the health sector. Nurse preparedness is needed to minimize the impact of disasters. Self-efficacy, caring and organizational commitment are important factors in nurse preparedness. The purpose of this study was to determine the effect of self-efficacy, caring, and organizational commitment on preparedness of nurses in dealing with patients during natural disasters. This research was correlational with a cross-sectional approach. The sample consisted of 24 nurses in the emergency room at Jampangkulon General Hospital. Data were collected using questionnaires, and statistical analysis was through simple linear regression. The results showed that most of the nurses had high self-efficacy, were caring and experienced moderate organizational commitment, and most were very ready for disaster preparedness. There was a significant effect of self-efficacy on preparedness ( $p=0.023)$, of caring on preparedness $(p=0.003$ ) and of organizational commitment on preparedness ( $p$ $=0.008$ ). Based on the results of the study, self-efficacy, caring and organizational commitment significantly impact nurse preparedness.
\end{abstract}

Keywords: self-efficacy, caring, organizational commitment, nurses, preparedness

\section{Introduction}

Preparedness is a series of activities to anticipate disasters through organizing and appropriate and efficient steps (Law of the Republic of Indonesia No. 24 of 2007). Disaster preparedness is very important for every major stakeholder as a subject who is directly involved when a disaster occurs [5].

The implementation of disaster preparedness does not only involve the government but also involves the community, especially health workers. According to [2] to maximize disaster management efforts in the health sector, health services must prepare professional health workers, one of which is nurses [6]. 
As the front line in health services, nurses have a big responsibility and role in handling victims of natural disasters. Currently, the need for nurses to handle disaster victims in the community is the biggest need, which is $33 \%$ of all health workers involved [3] Therefore, nurses are the first milestone that the community will look for when a disaster occurs [10].

With good nurse preparedness, the management provided is also good, thus avoiding fatalities, property losses and changes in community life in the future [4]. According to [5] nurses are required to prepare themselves to deal with disaster situations. Apart from the psychological conditions experienced by nurses during disasters, nurses must be able to be professional in these conditions [2]. Several factors can affect the disaster preparedness of nurses, including self-efficacy, caring and commitment of nurses themselves.

RSU Jampangkulon West Java Province is one of the hospitals owned by the Sukabumi Regency Government which the West Java Province took over. At Jampangkulon General Hospital, West Java Province, emergency services are available 24 hours, including general emergency services and obstetrics. Indeed, the ER is a unit that handles emergencies and is one of the main entrances to the hospital and will give the client's first impression of the hospital, for that fast, accurate service and prioritizing patient safety are a must in providing services in the emergency department.

Research related to disaster preparedness has been conducted several times, especially with the characteristics of society and the environment. However, research that links disaster preparedness with self-efficacy, caring and organizational commitment of nurses is still rarely done, especially disaster preparedness for nurses. Where as selfefficacy, caring and organizational commitment of nurses are very likely to affect the disaster preparedness of nurses in dealing with natural disaster patients, considering that nurses are one of the health workers who are at the forefront when a natural disaster occurs.

\section{Methods and Equipment}

The type of research used in this study is correlational research with approach crosssectional. The population in the study is all nurses in The Emergency Room JampangkuIon Hospital with a sample of 24 people. Sampling technique using Total Sampling.

Data collection in this study used a questionnaire and the statistical analysis used was simple linear regression analysis. 


\section{Result}

Based on Table 1, shows that the average age of the respondents is 32 years, the average length of work is 9 years, most of the respondents are educated D3 Nursing as many as 17 people (70.8\%), most of the respondents are women as many as 15 people (62.5\%), most of the respondents were married as many as 23 people (95.8\%), most of the respondents were non- civil servant status as many as 20 people (83.3\%), and most of the respondents had and never attended training and disaster simulation, each as many as 12 people (50.0\%).

Based on Table 2, it shows that most of the nurses' self-efficacy is high, as many as 14 people or $58.3 \%$, some nurses have good caring, as many as 22 people or $91.7 \%$, most of the nurses' organizational commitment is moderate, namely as many as 16 people or $66.7 \%$. Table 4.2 also show that most of the respondents have very ready disaster preparedness as many as 11 people or $45.9 \%$. Meanwhile, based on the combined preparedness index value according to LIPI-UNESCO, an index value of $70.81 \%$ is obtained, which means it is in the Ready category [7].

Based on Table 3, shows that self-efficacy affects disaster preparedness $(b=1.219$, $\left.p=0.023, R^{2}=0.214\right)$, caring affects disaster preparedness $\left(b=1.525, p=0.003, R^{2}=0.331\right.$, organizational commitment affects disaster preparedness $\left(b=2.791, p=0.008, R^{2}=0.280\right)$.

\section{Discussion}

The results showed that there was a significant influence between self-efficacy on disaster preparedness of implementing nurses in dealing with natural disaster patients. The results of this study are in line with the research of Shafithri [11] which states that there is a significant influence of individual self-efficacy on disaster preparedness. In addition, the results of research by [3] showed that there was a significant positive relationship between nurse self-efficacy and nurse preparedness in disaster management.

One of the factors that can affect disaster preparedness is self-efficacy [3]. Selfefficacy has been identified as having a significant influence on behavior when dealing with problems that are perceived to be less controlled. Individuals tend not to act if they think they do not have the competence to deal with disasters, while individuals who have high self-efficacy tend to be more prepared to face disasters, because selfefficacy increases the number of plans developed by individuals and their persistence in implementing them 14]. 
TABLE 1: Characteristics of Respondents

\begin{tabular}{|c|c|c|c|}
\hline No & Characteristics of Respondents & \multicolumn{2}{|c|}{ Average (year) } \\
\hline 1 & Age & \multicolumn{2}{|c|}{32} \\
\hline \multirow[t]{2}{*}{2} & Length of work & \multicolumn{2}{|c|}{9} \\
\hline & & $\mathbf{F}$ & $\%$ \\
\hline \multirow[t]{4}{*}{3} & Education & & \\
\hline & D3 Nursing & 17 & 70.8 \\
\hline & S1 Nursing & 1 & 4.2 \\
\hline & Nurse Profession & 6 & 25.0 \\
\hline \multirow[t]{3}{*}{4} & Gender & & \\
\hline & Man & 9 & 37.5 \\
\hline & Woman & 15 & 62.5 \\
\hline \multirow[t]{3}{*}{5} & Marital status & & \\
\hline & Marry & 23 & 95.8 \\
\hline & Not married yet & 1 & 4.2 \\
\hline \multirow[t]{3}{*}{6} & Job status & & \\
\hline & Civil servant & 4 & 16.7 \\
\hline & Non civil servant & 20 & 83.3 \\
\hline \multirow[t]{3}{*}{7} & Disaster Training & & \\
\hline & Once & 12 & 50.0 \\
\hline & Never & 12 & 50.0 \\
\hline \multirow[t]{3}{*}{8} & Disaster Simulation & & \\
\hline & Once & 12 & 50.0 \\
\hline & Never & 12 & 50.0 \\
\hline
\end{tabular}

The level of self-efficacy will have an influence on disaster preparedness where a nurse in dealing with disasters can provide confidence to be able to handle victims of natural disasters well and be ready to face future disasters. The higher the self-efficacy of nurses, the more prepared nurses are in dealing with disasters which are shown by strong belief in their ability to be involved in handling victims of natural disasters and tend to be more confident in taking an action for disaster emergency response [15].

Research conducted on 243 nurses in Israel revealed that self-efficacy was able to affect nurse preparedness [9]. Al Khalaileh, Bond and Alasad [10] state that selfefficacy has a role in changing disaster preparedness [13]. The results showed that there was a positive effect of self-efficacy on nurse preparedness in dealing with disasters. Respondents who have high self-efficacy values will have a high level of disaster preparedness. Meanwhile, respondents who have low self-efficacy values will have a low level of disaster preparedness.

The results showed that there was a significant influence between nurse caring on disaster preparedness of implementing nurses in dealing with natural disaster patients. 
TABLE 2: Univariate Analysis Of Research Variables

\begin{tabular}{|c|c|c|c|}
\hline \multirow[t]{2}{*}{ No. } & Variables & $\mathbf{F}$ & (\%) \\
\hline & Self-Efficacy & & \\
\hline 1. & High & 14 & 58.3 \\
\hline 2. & Moderate & 9 & 37.5 \\
\hline \multirow[t]{2}{*}{3.} & Low & 1 & 4.2 \\
\hline & Caring & & \\
\hline 1. & Good & 22 & 91.7 \\
\hline 2. & Enough & 2 & 8.3 \\
\hline \multirow[t]{2}{*}{3.} & Not enough & 0 & 0 \\
\hline & $\begin{array}{l}\text { Organizational } \\
\text { Commitment }\end{array}$ & & \\
\hline 1. & High & 8 & 33.3 \\
\hline 2. & Moderate & 16 & 66.7 \\
\hline \multirow[t]{2}{*}{3.} & Low & 0 & 0 \\
\hline & Disaster Preparedness & & \\
\hline 1. & Very ready & 11 & 45.9 \\
\hline 2. & Ready & 6 & 25.0 \\
\hline 3. & Almost Ready & 2 & 8.3 \\
\hline 4. & Less Ready & 2 & 8.3 \\
\hline 5. & Unready & 3 & 12.5 \\
\hline
\end{tabular}

TABLE 3: Simple Linear Regression

Variables
Self-Efficacy
Caring
Organizational
Commitment

P.
Value
0.023
0.003
0.008

\begin{tabular}{l|l} 
Unstandardized Coefficients B \\
Constant & Variables \\
15.674 & 1.219 \\
-58.453 & 1.525 \\
-31.534 & 2.791 \\
\hline
\end{tabular}
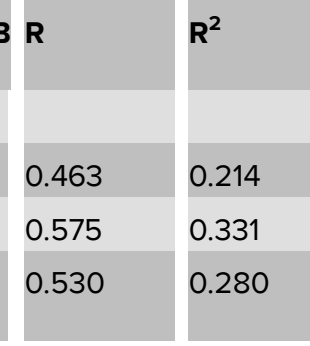

The results of this study are supported by research conducted by [8] which states that there is a relationship between nurse caring behavior and patient satisfaction in the Emergency Room (IGD). If patient satisfaction is achieved, the treatment provided by nurses to patients who are victims of natural disasters is well received and shows that nurses are very ready to deal with disaster situations. The results of (1). also showed that there was an increase in patient satisfaction after being given nursing care by nurses with caring behavior.

Caring behavior is one of the factors that can affect the disaster preparedness of nurses in dealing with patients who are victims of natural disasters. Based on ICN (2009), one of the roles of nurses in disaster-affected hospitals is as a care giver, nurses must perform disaster preparedness services and sort out physical and psychological 
problems that occur in patients [4]. In situations like this, patients really need attention, sensitivity, and caring attitude from nurses to respond to their complaints, so caring behavior is needed in nursing services in the emergency unit [8]. Especially for patients who are victims of natural disasters.

According [10], Nurse caring behavior will allow the establishment of harmonious interpersonal relationships between nurses and patients, can help and meet patient needs, which in turn can provide satisfaction to patients [16]. A nurse must have caring behavior in their services to patients, because the relationship between health care providers and patients is a factor that affects the process of satisfaction and recovery of the patient [8]

When patients are satisfied with the services provided by nurses, it will reflect the good quality of hospital services and the success of nurses in dealing with patients who are victims of natural disasters in the nurse's disaster preparedness efforts. The results showed a positive effect of caring on nurses' preparedness in dealing with disasters. Respondents with a high caring value will have a high level of disaster preparedness. Meanwhile, respondents who have a low caring value will have a low level of disaster preparedness.

The results of the study indicate that there is a significant influence between the organizational commitment of nurses on disaster preparedness of implementing nurses in dealing with natural disaster patients. The results of this study are in line with the research of [18]. which states that organizational commitment has a positive and significant effect on nurse performance. Nurses with high organizational commitment will be more likely to have good performance. With good performance, nurses will have a good level of disaster preparedness, and patients who are victims of natural disasters will be handled well.

According to [11], organizational commitment is an important component in the success of organizational performance, because it is a driving element for someone to do work alone or in groups [12]. Nurses who have a strong affective commitment will stay with the organization because they want to stay (because they want to). The nurses who have a strong continuance commitment because they have to stay with the organization (because they have to). Meanwhile, nurses who have a strong normative commitment because they feel that they have to live together (because they feel that they have to). Nurses with high commitment tend to feel happy at work because they have to embody what has become their belief in the organization. The hospital will greatly benefit because the performance of nurses tends to be stable or even increase. It is indicated that high organizational commitment will improve nurse performance. If nurses 
have good performance, nurses tend to be ready to handle patients, especially patients who are victims of natural disasters in the context of disaster preparedness carried out by nurses.

The results showed a positive effect of organizational commitment on nurses' preparedness in dealing with disasters. Respondents who have a high organizational commitment value will have a high level of disaster preparedness. Meanwhile, respondents who have a low organizational commitment value will have a low level of disaster preparedness.

\section{Conclusion}

Based on the results of the study, self-efficacy, caring, and organizational commitment can improve nurse preparedness. Nurses are expected to improve disaster preparedness by participating in various training and disaster simulations \& being involved in disaster-related institutions or organizations.

\section{Funding}

This work was supported by the Sukabumi School of Health Sciences

\section{Acknowledgement}

The authors would like to thank their colleague for their contribution and support to the research. They are also thankful to all the reviewers who gave their valuable inputs to the manuscript and helped in completing the paper.

\section{Conflict of Interest}

The authors have no conflict of interest to declare.

\section{References}

[1] Ariani TA, Aini N. Perilaku caring perawat terhadap kepuasan pasien rawat inap pada pelayanan keperawatan. Jurnal Keperawatan. 2018;9(1):58-64.

[2] Dwitanta S, Dahlia D. Peran perawat dan kesiapan darurat dalam menghadapi bencana pada penderita diabetes: Tinjauan literatur. Indonesian Journal of Nursing 
Health Science. 2020;5(1):48-60.

[3] Raikhanah, S. Hubungan efikasi diri dengan kesiapsiagaan perawat puskesmas dalam penanggulangan bencana di kabupaten poso [Thesis]. Yogyakarta: Universitas Gadjah Mada Yogyakarta; 2017.

[4] Sitorus, E., Mahendra, D., \& Batu, A. M.. Buku materi pembelajaran manajemen gawat darurat dan bencana. Jakarta: Program Studi Diploma Tiga Keperawatan Fakultas Vokasi Universitas Kristen Indonesia; 2019.

[5] Hadi, H., Agustina, S., \& Subhani, A.. Penguatan kesiapsiagaan stakeholder dalam pengurangan risiko bencana gempa bumi. Geodika: Jurnal Kajian IImu dan Pendidikan Geografi. 2019;3(1):30-40.

[6] Huriani, E., \& Sumarsih, G. Pengetahuan, keterampilan, kesiapan dan keinginan bekerja dalam situasi bencana pada perawat IGD RSUP Dr. M. Djamil Padang. Jurnal Kesehatan Medika Saintika. 2018;9(2):18-27.

[7] LIPI-UNESCO/ISDR. Kajian kesiapsiagaan masyarakat dalam mengantisipasi bencana gempa bumi dan tsunami. LIPI. Bandung; 2006.

[8] Listianingsih, L. T., Wijaya, Y. M., \& Indriany, K. Hubungan perilaku caring perawat dengan kepuasan pasien false emergency di unit gawat darurat rumah sakit cahya kawaluyan. STIKes Borromeus. Bandung. 2013.

[9] Melnikov S, Itzhaki M, Kagan I. Israeli nurses' intention to report for work in an emergency or disaster. Journal of Nursing Scholarship. 2014;46:134-142.

[10] Munandar A, Wardaningsih S. Kesiapsiagaan perawat dalam penatalaksanaan aspek psikologis akibat bencana alam: A literature review. Ejournal Umm. 2018;9(2):72-81.

[11] Shafithri R. Hubungan tingkat self-efficacy petugas kesehatan dengan kesiapsiagaan bencana gempa bumi di RSUD Dr. Zainoel Abidin [Thesis and Dissertation Unsyiah]. Universitas Syiah Kuala. Banda Aceh. 2016.

[12] Harsanto, B. A.. Pengaruh komitmen organisasi terhadap kinerja perawat di RS PKU muhammadiyah bantul. Jurnal Manajemen Kesehatan Yayasan R.S. Dr. Soetomo. 2019;5(2):154-164.

[13] Susila, I. M. D. P., Udaksana, M. A. W., \& A'ini, N. Hubungan persepsi dengan kesiapsiagaan bencana pada tenaga kesehatan. Jurnal Kesehatan Saelmakers Perdana (JKSP). 2020;3(1):91-96.

[14] Syarif, H., \& Mastura, M.. Hubungan self-efficacy dengan kesiapsiagaan bencana gempa bumi dan tsunami pada siswa sekolah menengah atas negeri 2 dan 6 banda aceh. Idea Nursing Journal, 2015;6(2):1-9. 
[15] Tumurang DO, llat V, Kalalo MYB. Pengaruh self-efficacy, kompleksitas tugas dan keahlian audit terhadap audit judgment auditor pada inspektorat provinsi sulawesi utara. Jurnal EMBA. 2019;7(3):3919-3928.

[16] Umayah EP. Hubungan perilaku caring perawat dengan tingkat kepuasan pasien di bangsal rawat inap wardah rs pku Muhammadiyah gamping. Yogyakarta: Naskah Publikasi, Universitas 'Aisyiyah Yogyakarta; 2017.

[17] Undang-Undang Republik Indonesia No. 24 tahun 2007 tentang penanggulangan bencana.

[18] Wicaksana SS. Pengaruh beban kerja dan komitmen organisasi terhadap kinerja perawat pada rumah sakit islam yogyakarta PDHI [Thesis, Program Studi Manajemen]. Yogyakarta: Universitas Negeri Yogyakarta; 2016. 